Quebec Cooperative Study

of Friedreich's Ataxia

\title{
Pyruvate Dehydrogenase Activity in the Liver, Brain and Adipose-Tissue of Lipid-Deprived Developing Rats. Effect of Minute Amounts of Polyunsaturated Fatty Acids.
}

\author{
C. LORIETTE, M. LAUNAY, D. LAPOUS, J. RAULIN
}

\begin{abstract}
The present experiment was carried out using the following diets: $\boldsymbol{F F}$, fat-free, and $\mathbf{L P}$ the same diet with $0.7 \%$ sunflower oil - given to the progeny of females kept on the FF diet since the mating. After $10 \mathrm{mM} \mathrm{Mg2+}$ activation of the PDH phosphatase, the rate of $[1$ $\left.{ }^{14} \mathrm{C}\right]$ pyruvate decarboxylation into acetylCoA ester units was determined in the liver, brain and adipose-tissue of the pair-fed developing rats. Results: In the male progeny, pyruvate dehydrogenase (PDH) activity was higher (61\%) in the LP group livers than in the FF group livers, at the end of the 13 week experiment. Such a difference was not observed in the two group brains up to the 91 days post-
\end{abstract}

RÉSUMÉ: Le régime FF (lipidoprive) ou $\boldsymbol{L P}$ (FF additionné de $0.7 \%$ d'huile de tournesol) est donné à des rats sevrés issus de mères gardées au régime $F F$ depuis l'accouplement. La vitesse de decarboxylation $d u\left[1-{ }^{14} \mathrm{C}\right]$ pyruvate est déterminée dans les tissus des jeunes rats, après activation in vitro de la pyruvate dehydrogénase (PDH) phosphatase par $\mathrm{MgCl}_{2} 10 \mathrm{mM}$. A partir du 48ème jour, l'activité $P D H$ est plus forte dans le groupe de tissus $L P$ que dans le groupe FF. Chez les mâles, la différence d'activité atteint $61 \%$ pour le foie, $94 \%$ pour le tissu- weaning, but was even larger (94\%) between adipose-tissues of the LP and FF groups. In the female progeny kept 12 weeks on the diets, PDH activity in the LP group tissues was also higher than in the FF group tissues: $63 \%$ in the liver, $43 \%$ in adipose-tissues, and less than $10 \%$ in the brain. Therefore, a minute amount of lipids high in linoleic acid appeared to increase $P D H$ activity, and especially in the liver and adipose-tissues of animals kept on a strictly fat-free diet. This stimulation of the PDH activity seems closely related to the phospholipid rehabilitation in the tissues (decrease in the trienoic: tetraenoic acid ratio values).

adipeux; chez les femelles, la différence est de $63 \%$ pour le foie, $43 \%$ pour le tissuadipeux, $10 \%$ pour le cerveau - à la fin des 12-13 semaines d'expérience. Une dose minime de lipide riche en acide linoléique augmente donc l'activité $P D H$ et tout particulièrement au niveau du foie et du tissu-adipeux, lorsque les jeunes rats sont gardés au régime strictement lipidoprive. La stimulation enzymatique paraît corrélée à la réhabilitation structurale des phospholipides tissulaires, avec nette réduction de la valeur du rapport triènes/tétraènes.
From Laboratoire Biologie Cellulaire Groupe Nutrition Cellulaire du C.N.R.S. Universite de Paris.

Reprint requests for the entire supplement on Friedreich's Ataxia (Phase Three, Part Two) to: Prof. Andre Barbeau, Clinical Research Institute of Montreal, 110 West Pine Avenue, Montreal, Quebec, Canada, H2W IR 7.

\section{INTRODUCTION}

The quantity of lipid in the diet and its composition play very important roles in the regulation of cellular enzymatic activities (Raulin et al, 1974). An enzymatic adaptation develops in rats when one raises the proportion of linoleic acid (C18:2) in dietary lipids.

An activation of the membrane enzymatic activity was observed especially for adenylate-cyclase (Counis, 1973; Louis et al, 1976; Englehard et al, 1976), and in the cytoplasmic lipolytic (Carreau et al, 1972) and lipogenic enzymes (Loriette et al, 1971, 1972, 1976) including acetyl-CoA ester producing enzyme activities. The growth of essential fatty acid (EFA) proportion in cellular lipids implies interactions which were observed up to the control of replication in adipose (Launay et al, 1969) and hepatic cells (Launay et al, 1981) with possible interference on the nucleolar methylation of RNAs linked to nascent DNA.

Because of its influence on the structure and fluidity of the subcellular and particular phospholipids (Raulin et al, 1971; Counis \& Jutisz, 1977), the proportion of unsaturated (UFAs) and of polyunsaturated (PUFAs) fatty acids affect the transport of substances through the cellular membranes (Kaduce et al, 1977). Moreover, our previous observations clearly suggest that the UFAs and PUFAs could be also involved in the various processes of the intermediary metabolism - and also allows a parallel with the requirement of UFAs which was found 
in a series of energy-linked reactions (Griffiths, 1976; Griffiths \& Hyams, 1977). Furthermore, oleic acid (C 18:1) and EFAs were also observed to be used in the biosynthesis of lipoic acid in the developing rat tissues (Carreau et al, 1975, 1977, 1979), indicating the possible participation of these longchain fatty acids in the construction of the PDH multienzyme complex, and especially in the synthesis of this covalently bound coenzyme.

Therefore, one preliminary experiment was carried out aiming to determine pyruvate dehydrogenase (PDH) activity in the tissues of EFA-deficient and of EFA-supplemented animals. When the progenies were maintained on the same fat-free (FF) diet as their mothers were since the 10th day postmating, PDH activity in the liver and brain of these developing rats (measured after $10 \mathrm{mM} \mathrm{Mg}{ }^{2+}$ activation of the PDH phosphatase) was lower than in the controls (Loriette et al, 1980). Control (LP) animals received the FF diet plus $0.7 \%$ sunflower oil. On the contrary, PDH activity in the FF group tissues was approximately identical to that found in the liver and brain of developing rats transferred, post-weaning time, to a $20 \%$ sunflower oil (SO) diet. The same observation (unpublished) was also made in the rat mothers' adiposetissues, when the females were transferred, post-suckling time, to the FF, LP or SO diet, even if $0.5 \%$ methyl linoleate was introduced into the LP diet instead of $0.7 \%$ sunflower oil. Therefore, these previous experiments (Raulin et al, 1980) indicated that a limiting amount of EFA, i.e. of linoleic acid, could produce the significant increase in PDH activity, when rats were kept on a lipid-deprived diet.

These previous observations made soon after weaning were thought to be the result of the pantothenate omission from the FF, LP and SO diets given to the mothers and to the developing rats. This vitamin omission seemed to precipitate the poor physiological conditions of animals kept on this strictly lipid-deprived FF diet. Therefore, the present experiment was carried out with the aim to pin-point the role of lipids high in essential fatty acids (EFA) given for supplementation of a fat-free - but vitamin well-balanced diet - as far as the PDH activity was concerned in the liver, brain and adipose-tissue of developing rats.

\section{MATERIALS AND METHODS}

Chemicals, enzymes and diets: Thiamin pyrophosphate chloride, coenzyme A sodium salt, sodium pyruvate, $\mathrm{NAD}^{+}$, lactate dehydrogenase (EC 1.1.1.27) and phosphotransacetylase (EC 2.3.1.8) were obtained from Sigma Chemical Co., Saint-Louis (MO). Sodium $\left[1{ }^{14} \mathrm{C}\right]$ pyruvate $(13.1 \mathrm{mCi} / \mathrm{mmol})$ was from Radiochemical Centre, Amersham (UK), or $(7.5 \mathrm{mCi} / \mathrm{mmol})$ from New England Nuclear (NEN), Boston (Ma), was used immediately or stored as already described (Taylor et al, 1973). Biofluor was obtained from NEN. Vitamins: vit. A, D-3, E, B-1, B-2, B-6 and biotin were purchased from Hoffmann-La Roche; vit. K, niacin, calcium pantothenate, folacin and inositol were from Prochimex; vit. B-12 was from A.E.C., Commentry (France). The lipid-deprived diet containing $29 \%$ casein, $63 \%$ sucrose, $5 \%$ Osborne-Mandel salt mixture, $2 \%$ cellulose and $1 \%$ vitamin mixture in casein, was obtained from U.A.R., Villemoisson sur Orge (France). Vitamin mixture (mg per g): 1.7 vit. A, 0.01 vit. D-3, 0.5 vit. $K, 2.0$ vit. E, 2.0 vit. B-1, 2.0 vit. B-2, 2.0 vit. B-6, 4.0 calcium pantothenate, 0.06 vit. B-12, 2.0 niacin, 0.1 folacin, 0.02 biotin, 20.0 inositol and 50.0 cholin chloride.

Preparation of animals: Wistar strain rats were used for the present study. Females were kept on our stock diet with $4 \%$ lipids until the 10 th day post-mating. They were then transferred to a fat-free (FF) diet, remaining on this until their progenies were weaned, i.e. 42 days post-mating. The progenies (male and female) were randomly distributed into two groups: $F F$, fed a fat-free diet, and $L P$, fed the fat-free diet supplemented with $0.7 \%$ (by wt) sunflower oil. Animals - 30 rats per group of males and females - were all pair-fed, and kept on the experimental diets until sacrified.
Preparation of tissue homogenates: As soon as possible after decapitation, the liver, brain and adipose-tissue were excised and homogenized in $9 \mathrm{vol}$ (brain, liver) or $4 \mathrm{vol}$ (adipose-tissue) of $20 \mathrm{mM}$ potassium phosphate buffer, $\mathrm{pH} 7.0$, containing $40 \%(\mathrm{v} / \mathrm{v})$ glycerol, using an Ultra-Turrax homogenizer ( 30 sec). Homogenates were then frozen in liquid nitrogen, and thawed (twice) prior to determination of PDH activity. Aliquots of adipose-tissue homogenates were taken by pipetting through the supernatant layer of lipids, while the brain and liver total homogenates were used for further determinations.

Determination of pyruvate dehydrogenase $(P D H)$ activity: $\left[1{ }^{-14} \mathrm{C}\right]$ pyruvate decarboxylation was measured in the liver, brain and adipose-tissue homogenates, using an assay system adapted from Wieland et al (1971) with $10 \mathrm{mM} \mathrm{MgCl} 1_{2}$ preincubation (30 min at $37^{\circ} \mathrm{C}$ ) for activation of the PDH phosphatase. Assays were carried out in gently shaken stoppered conical flasks at $37^{\circ} \mathrm{C}$. The assay was conducted in $100 \mathrm{mM}$ phosphate buffer, pH 8.0 ( $1.0 \mathrm{ml}$ final volume), containing $\mathrm{MgCl}_{2} \quad(2 \mathrm{mM})$, dithiothreitol $(0.9 \mathrm{mM}), \mathrm{NAD}^{+}(6$ $\mathrm{mM})$, thiamin pyrophosphate ( $2 \mathrm{mM})$, and coenzyme A $(0.1 \mathrm{mM})$. The complete reaction mixture also contained $125 \mu \mathrm{g}$ lactate dehydrogenase (EC 1.1.1.27) and $10 \mu \mathrm{g}$ phosphotransacetylase (EC 2.3.1.8). The reaction was initiated by addition of $0.25 \mu \mathrm{Ci}(0.1 \mathrm{ml})$ sodium $\left.\left[1-{ }^{14} \mathrm{C}\right]\right)$ pyruvate $50 \mathrm{mM}(0.05 \mathrm{mCi} / \mathrm{mmol})$ for the determination of the PDH activity in the liver and brain, and $10 \mathrm{mM}(0.25$ $\mathrm{mCi} / \mathrm{mmol}$ ) for the determination in adipose-tissue (final concentration 5 $\mathrm{mM}$ and $1 \mathrm{mM}$, respectively). The flasks were stoppered with corks carrying plastic wells in which were placed paper tapes (Whatman $\mathrm{Nr}$ 1) impregnated with $0.2 \mathrm{ml}$ of $3.0 \mathrm{M}$ $\mathrm{NaOH}$. The reaction stopped after 20 min incubation, with an injection of 1 $\mathrm{ml}$ trichloroacetic acid (15\%) through the serum cap. After acidification, the vials were shaken for an addition of 45 min. Radioactive $\mathrm{CO}_{2}$, collected on the paper tape, was counted in $10 \mathrm{ml}$ Biofluor. The determination of radioactivity was performed in an Inter- 
technique SL40 counter (Kontron, Vélizy-Villacoublay, France). Results were corrected for blank values obtained in vessels in which coenzyme A was omitted. Experimental values were 5 to 8 times the blank values. Linearity of the reaction was controlled between $5 \mathrm{~min}$. and $30 \mathrm{~min}$. of incubation, when $0.1-0.2 \mathrm{mg}$ protein was used per assay. Vmax was obtained beyond $1.0 \mathrm{mM}$ pyruvate concentration with the brain and liver preparations. According to Coore et al (1971), $1 \mathrm{mM}$ pyruvate concentration was convenient for PDH determination in adipose-tissues. Protein was determined by the method of Lowry et al (1951), with bovine serum (fat-free) albumin as a standard.
Lipid extraction from the tissues: The tissular lipids were extracted according to Bligh \& Dyer (1959), and the solvent soluble lipids were washed as already described (Carreau et al, 1977; Raulin \& Grundt, 1980). Gasliquid chromatography was used to determine fatty acid composition of the total lipids extracted from the liver and brain, and to determine fatty acid composition of adipose-tissue phospholipids, after acetonic precipitation. A glass-capillary column of Carbowax $20 \mathrm{M}$ (42 $\mathrm{m} \times 0.25 \mathrm{~mm}$ id) was used with an Erba-Science (Italy) Fractovap 2150 instrument, equipped with a MOD 232 Temperature Programmer. Temperature: injector and detector $230^{\circ} \mathrm{C}$, oven $180^{\circ} \mathrm{C}$, helium 0.7 bar.
Lipid conversion into fatty acid methyl esters was carried out according to Carreau \& Dubacq (1978).

\section{RESULTS}

Physiological and biochemical conditions of the developing rats.

As shown in Figure 1, body weight (BW) of the developing pair-fed rats increased at a similar rate during two weeks post-weaning, animals being kept on the FF or on the LP diet. Afterwards, body weight increased with differences which were soon observed to be significant among the two group rats. While body weight increase rose steadily almost until the end of the 84 and 91 day experiments, in the LP group of males and females,

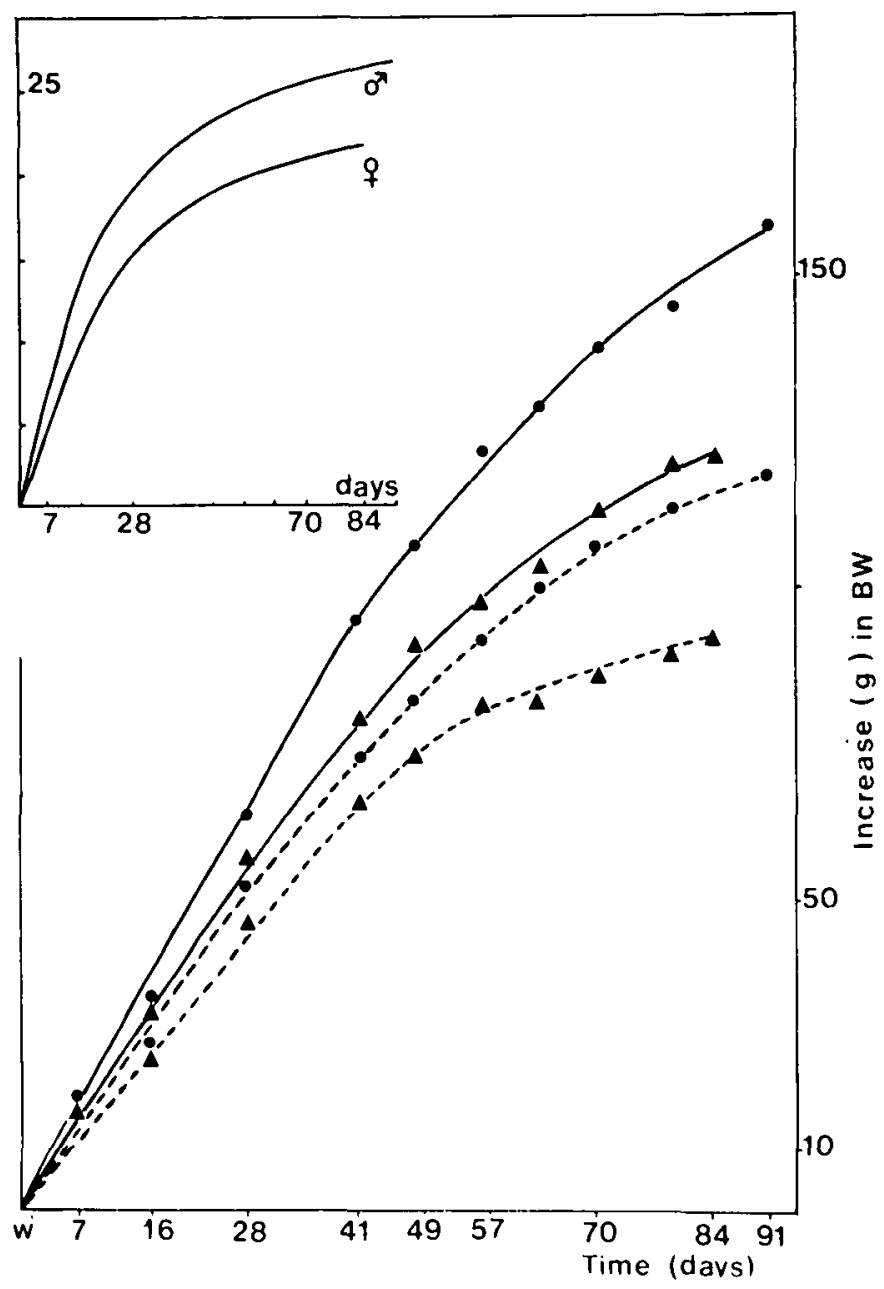

Figure 1 - Post-weaning increase (g) in body weight (BW) of the pair-fed developing rats. LP group males (- and females (A); FF group males ( - - - ) and females (A-C- A). Insert: Differences (\%) in BW between the LP and FF group of rats. Females $(\stackrel{\phi}{-})$, and males $\left(\longrightarrow \boldsymbol{\sigma}^{\top}\right) .30$ rats per group at weaning time (w).

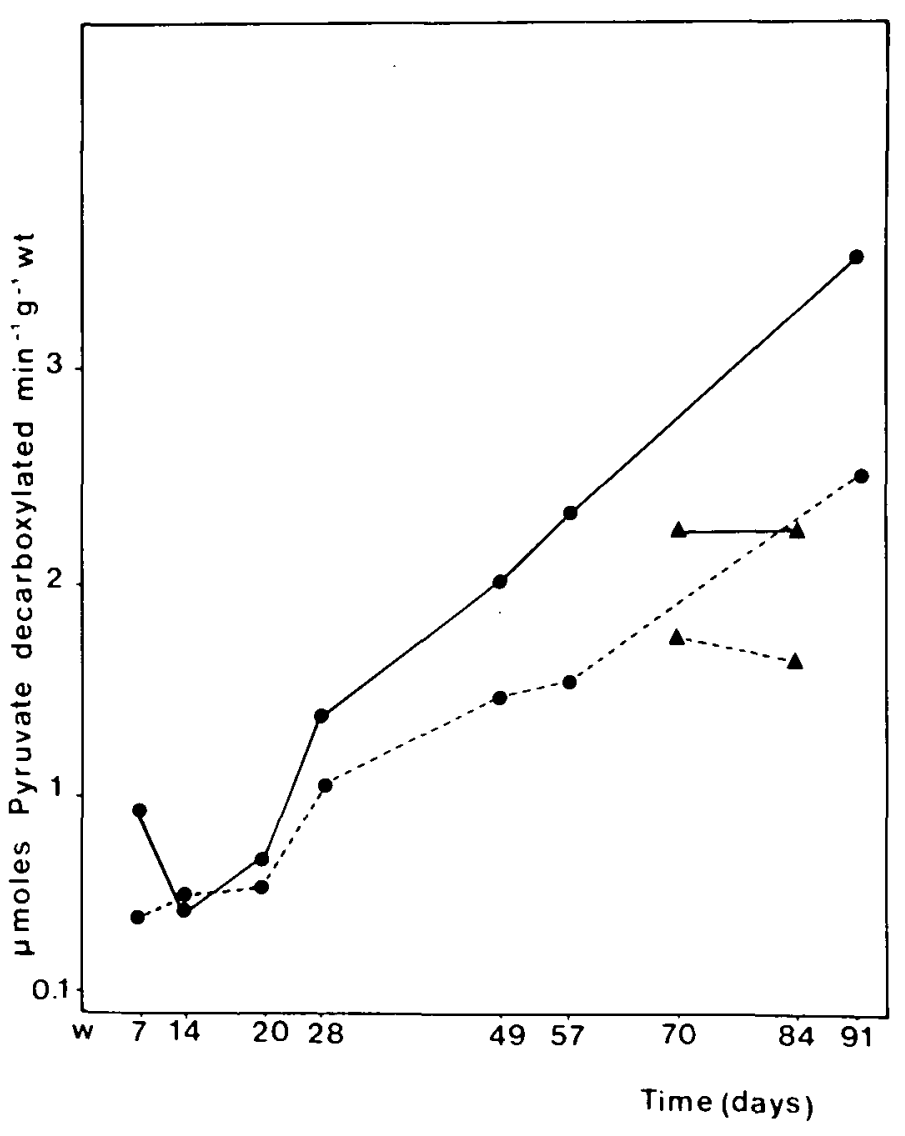

Figure 2 - Post-weaning pyruvate dehydrogenase total (PDH) activity of the LP male ( and $\mathrm{FF}$ female ( measured after $30 \mathrm{~min} .\left(37^{\circ} \mathrm{C}\right) 10 \mathrm{mM} \mathrm{MgCl} \mathrm{I}_{2}$ activation of the PDH phosphatase, and was calculated by subtraction from the results of the $\mathrm{CO}_{2}$ radioactivity formed in absence of added coenzyme $\mathrm{A}$ to the reaction flasks. $w=$ Weaning time.

Means of 2-5 determinations in triplicate. 
Table 1 - Fatty acid composition (moles percent) of the liver and brain lipide, and of the adipose-tiseue phospholipide - at the end of the 84 dey experiment (femele rats), and at the end of the 91 day experiment (mele rats). ${ }^{\circ}$ )

\begin{tabular}{|c|c|c|c|c|c|c|c|c|c|c|c|c|}
\hline $\begin{array}{l}\text { Dietary } \\
\text { group }\end{array}$ & $16: 0$ & $\begin{array}{l}16: 1 \\
(n-7)\end{array}$ & $18: 0$ & $\begin{array}{l}18: 1 \\
(n-9)\end{array}$ & $\begin{array}{l}18: 2 \\
(n-6)\end{array}$ & $\begin{array}{l}20: 1 \\
(n-9)\end{array}$ & $\begin{array}{l}20: 3 \\
(n-9)\end{array}$ & $\begin{array}{l}20: 4 \\
(n-6)\end{array}$ & $\begin{array}{l}22: 3 \\
(n-9)\end{array}$ & $\begin{array}{l}22: 4 \\
(n-6)\end{array}$ & $\begin{array}{l}22: 5 \\
(n-6)\end{array}$ & $\begin{array}{l}22: 6 \\
(n-3)\end{array}$ \\
\hline & LIVER & & & & & & & & & & & \\
\hline \multicolumn{13}{|l|}{$\mathrm{FF}$} \\
\hline \multirow[t]{2}{*}{ Female } & 25.3 & 13.3 & 13.4 & 29.7 & 1.8 & $T$ & 13.3 & 1.6 & 1 & - & 0.4 & 0.1 \\
\hline & \pm 0.4 & \pm 0.3 & \pm 0.4 & \pm 0.7 & \pm 0.2 & - & \pm 0.5 & \pm 0.2 & - & - & \pm 0.01 & \pm 0.01 \\
\hline \multirow[t]{2}{*}{ Male } & 25.2 & 9.0 & 12.9 & 32.0 & 1.3 & - & 16.9 & 1.6 & - & - & 0.2 & 0.1 \\
\hline & \pm 0.3 & \pm 0.3 & \pm 0.4 & \pm 0.8 & \pm 0.1 & - & \pm 0.5 & \pm 0.2 & - & - & \pm 0.01 & \pm 0.02 \\
\hline \multicolumn{13}{|l|}{ L.P } \\
\hline \multirow[t]{2}{*}{ Female } & 28.3 & 6.1 & 19.7 & 20.2 & 3.6 & - & 2.5 & 15.3 & - & - & 1.9 & 0.1 \\
\hline & \pm 0.5 & \pm 0.2 & \pm 0.5 & \pm 0.7 & \pm 0.2 & - & \pm 0.1 & \pm 0.6 & - & - & \pm 0.07 & \pm 0.02 \\
\hline \multirow[t]{3}{*}{ Male } & 27.8 & 8.2 & 14.1 & 25.8 & 4.4 & $T$ & 5.9 & 13.5 & - & - & 1.4 & 0.2 \\
\hline & \pm 0.9 & \pm 0.3 & \pm 0.4 & \pm 0.5 & \pm 0.2 & - & \pm 0.1 & \pm 0.4 & - & - & \pm 0.0 & \pm 0.03 \\
\hline & BRAIN & & & & & & & & . & & & \\
\hline \multicolumn{13}{|l|}{$\mathrm{FF}$} \\
\hline \multirow[t]{2}{*}{ Female } & 25.7 & 2.1 & 20.4 & 27.5 & - & I. 8 & 5.9 & 5.5 & 0.9 & 1.1 & 3.1 & 5.7 \\
\hline & \pm 0.4 & \pm 0.4 & \pm 0.6 & \pm 1.3 & - & \pm 0.4 & \pm 0.2 & \pm 0.4 & \pm 0.1 & \pm 0.1 & \pm 0.2 & \pm 0.4 \\
\hline \multirow[t]{2}{*}{ Male } & 25.2 & 1.4 & $20.7^{\circ}$ & 28.1 & - & 2.0 & 6.6 & 5.3 & 1.2 & 0.9 & 3.2 & 5.3 \\
\hline & \pm 0.5 & \pm 0.1 & \pm 0.5 & \pm 0.7 & - & \pm 0.4 & \pm 0.3 & \pm 0.3 & \pm 0.1 & \pm 0.3 & \pm 0.1 & \pm 0.6 \\
\hline \multicolumn{13}{|l|}{ LP } \\
\hline \multirow[t]{2}{*}{ Female } & 28.7 & 1.7 & 19.9 & 25.6 & - & 1.6 & 0.6 & 9.5 & 0.1 & 2.2 & 5.1 & 4.9 \\
\hline & \pm 1.1 & \pm 0.4 & \pm 0.5 & \pm 1.0 & - & \pm 0.5 & \pm 0.1 & \pm 0.4 & \pm 0.03 & \pm 0.1 & \pm 0.2 & \pm 0.3 \\
\hline \multirow[t]{3}{*}{ Male } & 27.8 & 1.0 & 19.7 & 25.4 & - & 1.4 & 1.0 & 9.7 & 0.2 & 2.4 & 4.9 & 6.4 \\
\hline & \pm 0.8 & \pm 0.1 & \pm 0.7 & \pm 1.3 & - & \pm 0.5 & \pm 0.1 & \pm 0.4 & \pm 0.1 & \pm 0.1 & \pm 0.2 & \pm 0.8 \\
\hline & \multicolumn{2}{|c|}{ ADIPOSE-TISSUE } & & & & & & & & & & \\
\hline \multicolumn{13}{|l|}{ FF } \\
\hline \multirow[t]{2}{*}{ Female } & 21.3 & 14.6 & 9.0 & 46.3 & 0.7 & - & 7.4 & 0.3 & 0.2 & $T$ & - & 0.1 \\
\hline & \pm 0.3 & \pm 0.5 & \pm 0.9 & \pm 1.0 & \pm 0.1 & - & \pm 0.1 & \pm 0.01 & \pm 0.0 & - & - & \pm 0.01 \\
\hline \multirow[t]{2}{*}{ Male } & 18.7 & 12.7 & 10.0 & 47.5 & 0.9 & - & 8.9 & 0.4 & 0.3 & $\mathrm{~T}$ & - & 0.3 \\
\hline & \pm 0.7 & \pm 0.7 & \pm 0.9 & \pm 0.9 & \pm 0.02 & - & \pm 0.1 & \pm 0.02 & \pm 0.02 & - & - & \pm 0.02 \\
\hline \multicolumn{13}{|l|}{ LP } \\
\hline \multirow[t]{2}{*}{ Female } & 27.2 & 9.3 & 14.7 & 35.2 & 4.9 & - & 1.2 & 5.2 & 0.2 & 0.2 & 0.4 & 0.4 \\
\hline & \pm 0.5 & \pm 1.1 & \pm 0.5 & \pm 0.7 & \pm 0.4 & - & \pm 0.2 & \pm 0.2 & \pm 0.04 & \pm 0.03 & \pm 0.05 & \pm 0.1 \\
\hline \multirow[t]{2}{*}{ Male } & 22.3 & 10.3 & 16.3 & 36.0 & 4.4 & - & 2.4 & 6.5 & 0.2 & 0.2 & 0.3 & 0.2 \\
\hline & \pm 0.4 & \pm 0.9 & \pm 0.6 & $\pm I .2$ & \pm 0.2 & - & \pm 0.4 & \pm 0.3 & \pm 0.07 & \pm 0.0 & \pm 0.03 & \pm 0.01 \\
\hline
\end{tabular}

-) Means \pm SEM of 4 rats Determinations in duplicate. 
respectively, body weight of the FF group rats increased to near plateau values - which was reached as soon as ca 57 days post-weaning in the FF group female rats. Other symptoms of EFA deficiency were obvious from the 3rd week post-weaning, when animals were kept on the FF diet: increase in water consumption and low food intake. After 7 weeks on the FF diet, alopecia and dermatitis were also observed.

Fatty acid composition of the lipids extracted from the rat tissues was studied at the end of the 84 day experiment (females) and of the 91 day experiment (males). The trienoic: tetraenoic acid ratio was quantified to verify biochemically EFA deficiency in these animals. There was a considerable accumulation of eicosatrienoic acid (C20:3 n-9) in the FF group liver lipids, and in the FF group adipose-tissue phospholipids when compared to the little amounts found in the LP group tissues (Table 1). Consequently, the trienoic: tetraenoic acid ratio values $(C 20: 3 n-9+C 22: 3$ n-9 to $C 20: 4$ n-6 + C22:4 n-6 ratio values) were especially high and up to 12 in the FF group livers and adiposetissues (Table 2). Values for this ratio were lower and close to 1.0 in the FF group brains. On the contrary, little trienoic acids were found in the LP group livers, adipose-tissues and brains, and ratio values were close to 0.2 in the three tissues.

\section{$P D H$ activity in the liver, brain and adipose-tissue}

PDH activity was determined in the liver and brain from the 7 th day postweaning of the rats transferred to the LP or to the FF diet. Adipose-tissue was studied only at the end of the experiment ( 84 and 91 days postweaning).

Wide variations in $\mathrm{PDH}$ activity were obtained from individual animals due to the familial origin of the offsprings. Nevertheless, some general increase in PDH activity (Fig. 2, Table 3) was observed in the two group tissues, PDH activity being found lower in the liver and brain prior to the 28th day post-weaning (i.e. 28 days on the experimental diets) than afterwards (PDH activity in the brain: 1127-1271 nmoles pyruvate decarboxylated $\mathrm{min}^{-1}$ $\mathrm{g}^{-1}$ wet weight before 28 days, vs 1464 1856 after 28 days).

Male rats: Some differences in PDH activity were also found among the two group tissues, especially obvious among the two group livers (Table 3 ). The LP group livers had PDH activity $100 \%$ higher than the FF group livers 7 days after the start of the experiment. Thereafter, the LP vs FF differences were much less $(-8 \%$ at 14 days, $21 \%$ at 28 days), however increased progressively up to $61 \%$ after 91 days of the experiment. In the brain, no differences in PDH activity were found between the LP and FF groups (Table 3 ), although some of the LP group brains showed a decrease in PDH activity (up to $18 \%$ at the end of the 91 days experiment), when compared to the FF group. As for the LP and FF group epididymal adipose-tissues (excised at the $91 \mathrm{st}$ day), the

Table 2 - Trienoic : Tetraenoic acid ratio values obtained at the end of the 84 day experiment (female rats), and at the end of the 91 day experiment (male rats). Fatty acid analysis in the total lipids of the liver and brain, and in the adipose-tissue phospholipids after acetonic precipitation. ${ }^{\circ}$ )

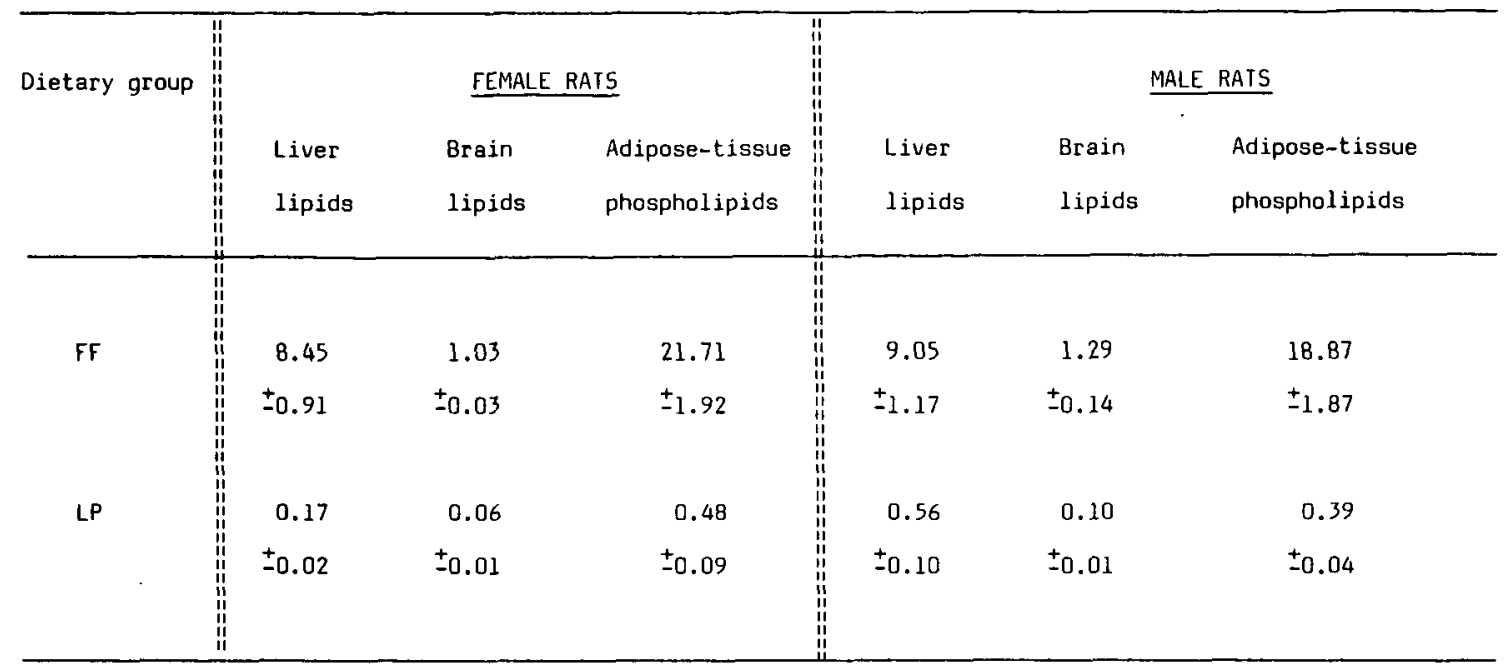

-) Means \pm SEM of 4 rats.

Determinations in duplicate. The ratio values were calculated from the data of fatty acid analysis (see Table 1), and concern the following fatty acid (molar percent) $20: 3 n-9+27: 3 n-9$ to $20: 4 n-6+22: 4 n-6$ rallo values. 
differences in PDH activity were even larger than those found in the livers. Means of 4 determinations in triplicate: 18.9 nmoles pyruvate decarboxylated $\min _{-1} \mathrm{mg}_{-1}$ protein, vs 9.7 , in the LP and FF group male adipose-tissues, respectively, i.e. $94 \%$ difference among the two groups.

Female rats: The determination of PDH activity was carried out with females kept 70 and 84 days postweaning on the experimental diets.
PDH activity of the liver was observed to be lower at comparative ages in the female rats than in the male rats, regardless of the LP or FF group considered (Table 3, Fig. 2). The differences in PDH activity between the two group livers were obvious at the mentioned times ( 70 and 84 days), and were found to be $45 \%$ and $63 \%$ between the LP and the FF group, respectively. No differences in $\mathrm{PDH}$ activity were found among the two group brains (Table 3), although some of the LP group brains showed an increase in PDH activity at 70 and 84 days of experiment (5-21\%), when compared to the FF group brains. The differences in PDH activity between the LP and FF group perigenital adipose-tissues of the females were small $(43 \%)$ when compared to those found among the two group adiposetissues of the males (see above). Means of 4 determinations in triplicate: 6.6 nmoles pyruvate decarboxylated $\min ^{-1}$ $\mathrm{mg}^{-1}$ protein, vs 4.6 , in the LP and FF

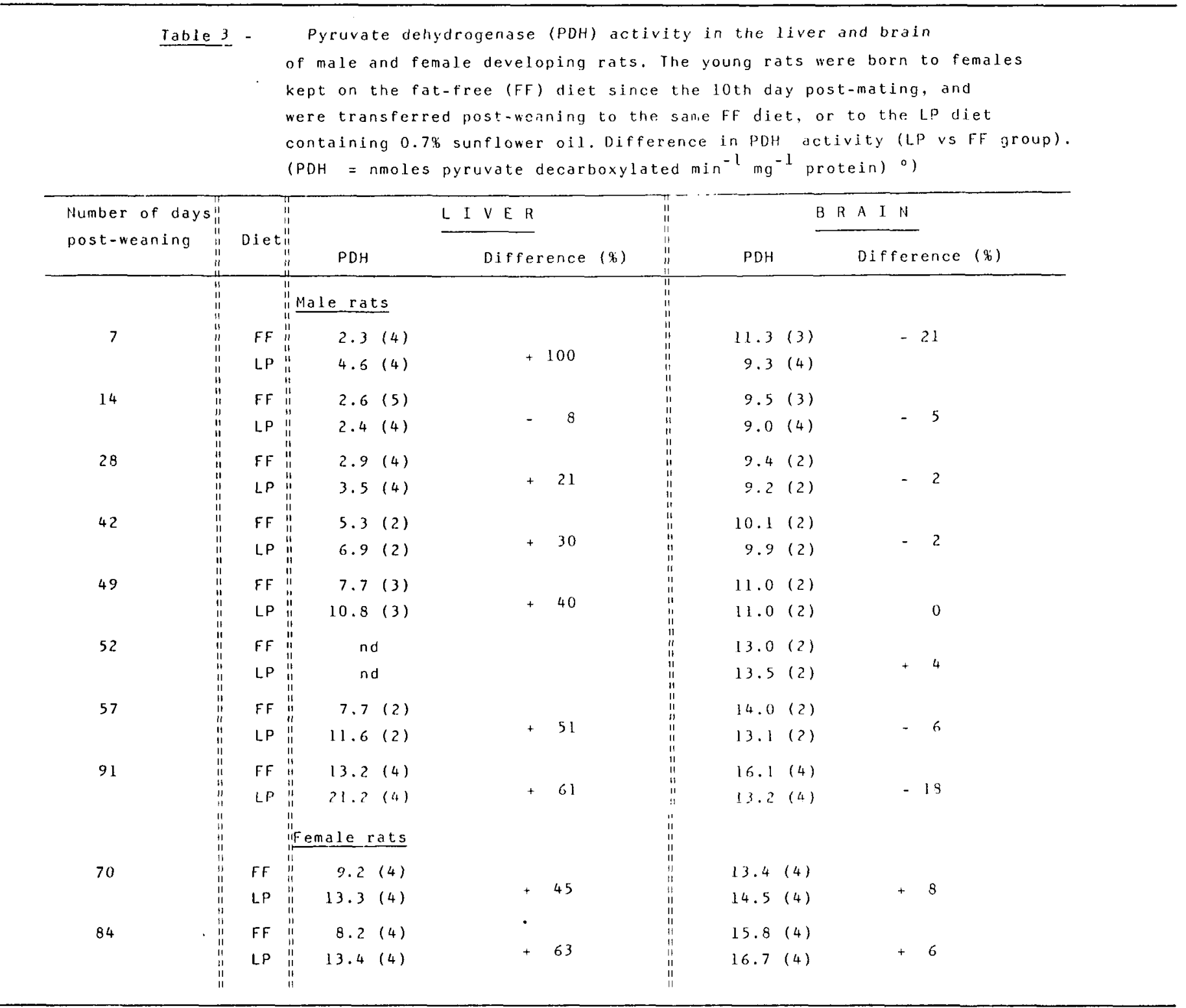

-) PDH activity was calculated by substraction of the co radioactivity obtained in absence of added coenzyme $A$ (as described in the Methods). Means of ()rats. lieterifinations in triplicate. Individual varlations in $\mathrm{PDH}$ activity according to the familial origin of the offsprings were observed. 
group females adipose-tissues, respectively.

\section{DISCUSSION}

Several experiments have indicated the multiple effects of fatty acids on PDH activity. Long-chain fatty acylCoA (and -carnitine) esters are wellknown to bring about net decrease in the active dephosphorylated form of this interconvertible enzyme (Wieland et al, 1971; Portenhauser \& Wieland, 1972; Reed, 1974; Lamers \& Hülsman, 1974; Denton et al, 1975; Taylor et al, 1975; Mapes \& Harris, 1975; Walajtys-Rode, 1976; Randle, 1978). According to Stansbie et al (1975) this effect is due only to a feedback-type mechanism which occurs under control of the acetyl-CoA ester - the end-product of PDH activity and of beta-oxidation. The acyl-CoA ester effect is also dependent on the concentration of pyruvate in the medium (Walajtys-Rode, 1976), and at low pyruvate concentrations near to $0.05 \mathrm{mM}, 0.1 \mathrm{mM}$ octanoate, oleate and beta-hydroxybutyrate were described to cause a stimulation of pyruvate decarboxylation in the perfused rat liver (Scholz et al, 1978), and in isolated rat liver mitochondria (Dennis et al, 1978).

In the present assays, the ratio of active to inactive forms of the PDH multienzyme complex was not measured. PDH activity was determined at high pyruvate concentrations ( 1 and $5 \mathrm{mM}$ ), and following $10 \mathrm{mM} \mathrm{Mg} 2+$ activation of the PDH phosphatase. Therefore the net decrease in PDH activity which was observed in the FF group tissues, suggests alterations in some of the liver and adipose-tissue PDH complex constituents of the lipid-deprived animals (Stansbie et al, 1975; Hutson \& Randel, 1978). On the other hand, UFAs and PUFAs seem to play a role in the biosynthesis of lipoic acid (coenzyme of pyruvate dehydrogenase) in mammals (Carreau et al, 1975, 1977, 1979).

During the first weeks of experiment, little differences in PDH activity were found between the LP and FF group livers and brains (Table 3 ). From the 7 th week, and to the end of the 13 week experiment, PDH activity was higher in the LP group livers, but was approximately identical in the two group brains. These results contrast with the previous observations (Raulin et al, 1980), obtained from developing rats receiving poor vitamin-balanced diets. In this latter case - PDH activity was low in both the FF group livers and brains - when compared to the LP group tissues. The comparison of the previous and present results indicates that the lack of vitamin, which influences the evolution of EFA deficiency - as already described (Dhopeshwarker \& Subramanian, 1981), could also influence PDH activity - at least when animals are kept on a lipid-deprived diet.

The minute amount of linoleic acid $(0.45 \%)$ included in the present LP diet by addition of $0.7 \%$ sunflower oil, was not enough to eliminate trienoic acids entirely from the LP group tissular lipids (Mohrhauer \& Holman, 1963; Caster et al, 1976; Mead, 1968; Galli, 1971; Alfin-Slater \& Aftergood, 1967). However, the proportion of trienoic acids was significantly lower than in the FF group tissular lipids, where there was a considerable accumulation of C20:3. Moreover, the limiting dose of EFA given in the present experiment to the pair-fed animals, greatly improved the LP group, physiologically. The FF group animals had marginal growth after 3 weeks post-weaning, and obviously suffered characterized visible symptoms of EFA deficiency, with presumed changes in tissue structures (Alfin-Slater \& Bernick, 1958).

If we assume that the LP group developing rats grew up satisfactorily (Fig. 1) - although at a lower rate than animals fed ad libitum - and were in a proper physiological condition, PDH activity in the LP group livers, brains and adipose-tissues can be accepted as control values. In comparison, the FF group livers (Fig. 2) and adipose-tissues showed low PDH activity. Therefore, PDH activity was low when the tissue contained high level of $\mathrm{C} 20: 3$ (FF group livers and adipose-tissues), and approximately identical to the LP "control" values when the tissue contained low level of C20:3 (FF group brains). The present data also suggest that the minute amount of linoleic acid ( $67 \%$ of the added $0.7 \%$ sunflower oil) given post-weaning to the developing rats, preserved the integrity of phospholipids in cellular membranes namely of the miochondrial membranes (Bailey et al, 1967) - and was adequate to cover the PDH multienzyme PUFA requirements for correct operation. This hypothetical suggestion could be made in view of the structural specificity of phospholipids, for activation of the crystalline pyruvate oxidase of $E$. coli (Cunningham \& Hager, 1971), and of other enzymes (Isaacson et al, 1979; Fleischer et al, 1979; Infante \& Kinsella, 1979).

In conclusion, the present experiment was carried out to answer questions concerning the possible influence of lipids high in linoleic acid on the rate of acetyl-CoA ester production from the carbohydrates. PDH activity was therefore determined in the tissues of developing rats, aiming to investigate $\left[1-{ }^{14} \mathrm{C}\right]$ pyruvate decarboxylation, with regard to the following dietary conditions: 1/ progenies were maintained postweaning on the same FF diet as their mothers were, $2 /$ progenies were transferred to a $0.7 \%$ sunflower oil $(0.45 \%$ linoleic acid) supplemented diet. The results indicated that the ${ }^{14} \mathrm{CO}_{2}$ production (and, consequently, the acetyl-CoA ester production) measured after $10 \mathrm{mM} \mathrm{Mg}^{2+}$ activation of the PDH phosphatase, was dependent upon the nutritional and physiological conditions of these animals. Three main factors influenced PDH multienzyme complex activity: the familial origin of the offsprings, the sex of animals (at the end of the 10-13 week post-weaning experiment), and, obviously, the addition of the minute amount of lipids - high in linoleic acid to their lipid-deprived diet. Therefore, the more active synthesis of acetylCoA ester units, which increase with time in the lipid-supplemented LP group animals, was especially noticeable in the liver and adiposetissue after the 7th week post-weaning, i.e. when the symptoms of EFA deficiency were obvious in the nonsupplemented FF group animals.

Incidentally, our present results fit 
well with the working hypothesis and tentative explanation (Barbeau, 1980) for relative deficiency in PDH activity and in linoleic acid, in Friedreich's ataxia. Such a pathogenic mechanism was derived from the observations of possible impairment in PDH activity with acetyl-CoA deficits (Barbeau, 1975; Blass, 1976), and from the finding of a lower percentage of linoleic acid in red blood cell phospholipids (Huang et al, 1980). It was also thought that the multisystem disease characterizing Friedreich's ataxia might be related to another form of EFA deficiency - since lecithins were claimed to act positively on these pathological disorders (Barbeau, 1978).

\section{ACKNOWLEDGEMENTS}

This work was supported in part by grants from La Fondation pour la Recherche Medicale Française, from l'Institut National de la Santé et de la Recherche Médicale (78.1.251.7), and from la Délégation Générale pour la Recherche Scientifique et Technique (ACC 79.7.1476). Presented in parts at the ISF-AOCS meeting, New York (NY), A pril 27-May 1 (1980), and at the 12th Int. Congress of Nutrition Workshop "Pyruvate Dehydrogenase and Lipids", San Diego (CA), August 20, 1981.

\section{REFERENCES}

ALFIN-SLATER, R.B. \& BERNICK, S. (1958). Changes in tissue lipids and tissue histology resulting from essential fatty acid deficiency in rats. Amer. J. Clin. Nutr., 6, 613-624.

ALFIN-SLATER, R.B. \& AFTERGOOD, L. (1976). Essential fatty acids. Recent developments. in: Medicinal Chemistry. Lipid Pharmacology, Vol. 2-Il, (Paoletti, R. \& Glueck, C.J., eds) pp. 43-82, Acad. Press, N.Y.

BAILEY, E., TAYLOR, C.B. \& BARTLEY, W. (1967). Turnover of mitochondrial components of normal and essential fatty acid-deficient rats. Biochem. J., 104, 10261032.

BARBEAU, A. (1975). Preliminary studies on pyruvate metabolism in Friedreich's ataxia. Trans. Am. Neurol. Ass., 100, 164-165.

BARBEAU, A. (1978). Emerging treatments: replacement therapy with choline or lecithin in neurological diseases. Can. J. Neurol. Sci., 5, 157-160.

BARBEAU, A. (1980). Friedreich's ataxia 1980. An overview of the physiopathology. Can. J. Neurol. Sci., 7, 455-468.

BLASS, J.P., KARK, R.A.P. \& MENON, N.K. (1976). Low activities of the pyruvate and oxoglutarate dehydrogenase complexes in five patients with Friedreich's ataxia. New Engl.J. Med., 295, 62-67.

BLIGH, E.G., \& DYER, W.J. (1959). A rapid method of total lipid extraction and purification. Can. J. Biochem. Physiol., 37, 911 917.

CARREAU, J.P., LORIETTE, C., COUNIS, P. \& KETEVI, P. (1972). Démasquage présumé des récepteurs de la noradrénaline par enrichissement en acide linoléique des phospholipides membranaires de la cellule adipeuse. I. Activité lipase. Biochim. biophys. Acta, 280, 440-443.

CARREAU, J.P., LAPOUS, D. \& RAULIN, J. (1975). Un dérivé vraisemblablement essentiel de l'acide linoléique: l'acide lipoïque, coenzyme universel de l'oxydation des acides alpha-cétoniques. C.R. Acad., Paris, 281, 941 1-944.

CARREAU, J.P., LAPOUS, D. \& RAULIN, J. (1977). Signification des acides gras essentiels dans le métabolisme intermédiaire. Hypothèses sur la synthèse de l'acide lipoïque. Biochimie, 59, 487-496.

CARREAU, J.P. \& DUBACQ, J.P. (1978). Adaptation of a macro-scale method to the micro-scale for fatty acid methyl transesterification of biological lipid extracts. $J$. Chromato., 151, 384-390.

CARREAU, J.P. (1979). Biosynthesis of lipoic acid via unsaturated fatty acids. in: Meth. Enzymol., vol 62, Vitamins \& Coenzymes, Part D (McCormick, D.B. \& Wright, L.D., eds), pp. 152-158, Acad. Press, N.Y.

CASTER, W.O., ANDREWS, J.W., JR., MOHRHAUER, H. \& HOLMAN, R.T. (1976). Effect of essential and nonessential fatty acids in complex mixture on fatty acid composition of liver lipids. J. Nutr., 106, 1809-1816.

COORE, H.G., DENTON, R.M., MARTIN, B.R. \& RANDLE, P.J. (1971). Regulation of adipose tissue pyruvate dehydrogenase by insulin and other hormones. Biochem. J., $125,115-127$.

COUNIS, R. (1973). Dèmasquage présumé des récepteurs de la noradrénaline par enrichissement en acide linoléique des phospholipides membranaires de la cellule adipeuse. II. Activités adenylcyclase et phosphodiesterase. Biochim. biophys. Acta, 306, 391-395.

COUNIS, R. \& JUTISZ, M. (1977). Temperature dependence of adenylate cyclase activity from rat white adipocytes. Molec. Cell Endocrinol., 7, 313-324.

CUNNINGHAM, C.C. \& HAGER, L.P. (1971). Crystalline pyruvate oxidase from $\mathrm{E}$. coli. Phospholipid as an allosteric effector for the enzyme. J. Biol. Chem., 246, 15831589.

DENNIS, S.C., DeBUYSERE, M., SCHOLZ, R. \& OLSON, M.S. (1978). Studies on the relationship between ketogenesis and pyruvate oxidation in isolated rat liver mitochondria. J. Biol. Chem., 253, 2229 2237.

DENTON, R.M., RANDLE, P.J., BRIDGES, B.J., COOPER, R.H., KERBEY, A.L., PASK, H.T., SEVERSON, D.L. STANSBIE, D. \& WHITEHOUSE, S (1975). Regulation of mammalian pyruvate dehydrogenase. Molec. Cell. Biochem., 9. 27-53.

DHOPESCHWARKAR, G.C., SUBRAMANIAN, C., GAN-ELEPANO, M. \& MEAD, J.F. (1981). Lack of vitamin-E in the diet leads to essential fatty acid (EFA) deficiency. I2th Int. Congr. Nutrition, San Diego, CA, Abstract 782.

ENGELHARD, V.H., ESKO, J.D., STORM, D.R. \& GLASER, M. (1976). Modification of adenylate cyclase activity in LM cells by manipulation of the membrane phospholipid composition in vivo. Proc. Natl. Acad. Sci. $73,4482-4486$.

FLEISCHER，S., MCINTYRE，J.D., STOFFEL, W. \& TUNGGAL, B.D. (1979). Carbon-13 nuclear magnetic resonance studies of the interaction of lecithin with purified D - beta- hydroxybutyrate apodehydrogenase, a lipid-requiring enzyme. Biochemistry, 18, 2420-2429.

GALLI, C., WHITE, H.B., JR. \& PAOLETTI, R. (1971). Lipid alterations and their reversion in the central nervous system of growing rats deficient in essential fatty acids. Lipids, 6, 378-387.

GRIFFITHS, D.E. (1976). Studies of energylinked reactions. Net synthesis of adenosine triphosphate in isolated adenosine triphosphate synthase preparations: a role for lipoic acid and unsaturated fatty acids. Biochem.J., 160, 809-812.

GRIFFITHS, D.E. \& HYAMS, R.L. (1977). Oxidative phosphorylation: a role for lipoic acid and unsaturated fatty acids. Biochem. Soc. Trans., 5, 207-208.

HUANG, Y.S., MARCEL, Y.L., VEZINA, C. BARBEAU, A. \& DAVIGNON, J. (1980). Lecithin: cholesterol acyltransferase activity and fatty acid composition of erythrocyte phospholipids in Friedreich's ataxia. Can.J. Neurol. Sci., 7, 429-434.

HUTSON, N.J. \& RANDLE, P.J. (1978). Enhanced activity of pyruvate dehy. drogenase kinase in rat heart mitochondria in alloxan-diabetes or starvation. Febs Lett. $92,73-76$.

INFANTE, J.P. \& KINSELLA, J.E. (1979) Co-ordinate regulation of ethanolamine kinase and phosphoethanolamine cytidyltransferase in the biosynthesis of phosphatidylethanolamine in rat liver. Evidence from essential fatty acid-deficient animals. Biochem. J., 179, 723-725.

ISAACSON, Y.A., DEROO, P.W., ROSENTHAL, A.F., BITTMAN, R., MCINTYRE, J.O., BOCK, H.G., GAZZOTTI, P. \& FLEISCHER, S. (1979). The structural 
specificity of lecithin for activation of 1 purified D - beta - hydroxybutyrate apodehydrogenase. J. Biol. Chem., 254. 117-126.

K A D UCE, T.L., AW A D. A.B., FONTENELLE, L.J. \& SPECTOR, A.A. (1977). Effect of fatty acid saturation on alpha-aminoisobutyric acid transport in Ehrlich ascites cells. J. Biol. Chem., 262. 6624-6630.

LAMERS, J.M.J. \& HÜLSMANN, W.C. (1974). The effects of fatty acids on oxidative decarboxylation of pyruvate in rat small intestine. Biochim. biophys. Acta, 343, 215-225.

LAUNAY, M., DAUVILLIER, P. \& RAULIN, J. (1969). Développement du tissu adipeux. Radioactivité spécifique des acides nucléiques et rôle des acides gras polyinsaturès. Bull. Soc. Chim. biol., 51, 95104.

LAUNAY, M., LAPOUS, D. \& RAULIN, J. (1981). Control of replication by dietary lipids and namely by linoleic acid in liver and adipose-tissue of developing rats. Progr. Lipid Res., 20, 331-338.

LORIETTE, C., JOMAIN-BAUM, M., MACAIRE, I. \& RAULIN, J. (1971). Lipogenèse de nova et insaturation des lipides exogènes dans le tissu adipeux du rat. Eur.J. Clin. Biol. Res., 16, 366-372.

LORIETTE, C. \& RAULIN, J. (1972). Commentaire sur l'effet régulateur de la lipogenèse par les acides gras polyinsaturés. Activité acétyl-CoA carboxylase du foie et du tissu adipeux. Biochimie, 54, 1467-1471.

LORIETTE, C., LAPOUS, D. \& RAULIN, J. (1976). Développement foetal et néonatal du tissu adipeux brun du cobaye et du rat. Transfert foeto-placentaire ou lacté des acides gras essentiels: lipogenèse et morphologie. J. Physiol., 72, 59-77.

LORIETTE, C., LAUNAY, M. \& RAULIN, J. (1981). Polyunsaturated oils and pyruvate dehydrogenase activity. J. Amer. Oil Chem. Soc., 57, A 334

LOUIS, S.L., BRIVIO-HAUGLAND, R.P. \& WILLIAMS, M.A. (1976). Effect of essential fatty acid deficiency on activity of liver plasma membrane enzymes in the rat. J. Supramolec, Struct., 4, 487(447)496(456).

LOWRY, O.H., ROSENBROUGH, N.J., FARR, A.L. \& RANDALL, R.J. (1951). Protein measurement with the Folin phenol reagent. In: Meth. Enzymol., vol 3, (Colowick, S.P. \& Kaplan, N.O., eds) pp. 447-454, Acad. Press, N.Y.

MAPES, J.P. \& HARRIS, R.A. (1975). Regulatory function of pyruvate dehydrogenase and the mitochondrion in lipogenesis. Lipids, 10, 757-764.

MEAD, J.F. (1968), The metabolism of the polyunsaturated fatty acids. in: Progr. Chem. Fats and other Lipids, vol 9, Part 2 (Holman, R.T., ed.) pp. 161-194, Pergamon Press, N.Y.

MOHRHAUER, H. \& HOLMAN, R.T (1963). The effect of dose level of essential fatty acid upon fatty acid composition of the rat liver. J. Lipid Res., 4, 151-159.

PORTENHAUSER, R. \& WIELAND, O. (1972). Regulation of pyruvate dehydrogenase in mitochondria of rat liver. Eur. $J$. Biochem. 31, 308-314.

RANDLE, P.J. (1978). Pyruvate dehydrogenase complex - meticulous regulator of glucose disposal in animals. TIBS, 3, 217 219.

RAULIN, J., LAPOUS, D., DAUVILLIER, P. \& LORIETTE, C. (1971). Remaniements structuraux du tissu adipeux et apport excessif d'acides gras essentiels. Nutr. Metab., 13, 249-265.

RAULIN, J., LORIETTE, C., LAUNAY, M., LAPOUS, D., GOUREAU-COUNIS, M.F., COUNIS, R. \& CARREAU, J.P. (1974). The effect on regulation of adiposetissue differentiation and evolution of excessive doses of essential fatty acids. in: The Regulation of Adipose-Tissue Mass (Vague, J. \& Boyer, J., eds) pp. 32-34, Excerpta med., Series 315, Elsevier Publ., Amsterdam.

RAULIN, J. \& GRUNDT, I.K. (1980). Incorporation of ${ }^{14} \mathrm{C}$ from carboxyl-labeled oleoyl-, linoleoyl- and arachidonoyl-CoA into water-soluble and insoluble fractions of rat liver slices. Methodology for in vitro experiments. Anal. Biochem., 101, 204-214.

RAULIN, J., LAUNAY, M., LORIETTE, C., LAPOUS, D. \& BOUCHÈNE, M. (1980). Implication of essential fatty acids in pyruvate dehydrogenase activity. in: Natural Sulfur Compounds, Novel Biochemical and Structural Aspects (Cavallini, D., Gaull, G.E. \& Zappia, V., eds) pp. 435442, Plenum Publ. Co., N.Y.

REED, L.J. (1974). Multienzyme complexes. Accounts Chem. Res., 7, 40-46.

SCHOLZ, R., OLSON, M.S., SCHWAB, A.J., SCHWAB, U., NOELL, C. \& BRAUN, W. (1978). The effect of fatty acids on the regulation of pyruvate dehydrogenase in perfused rat liver. Eur. J. Biochem., 86, 519 530.

STANSBIE, D., DENTON, R.M. \& RANDLE, P.J. (1975). Alterations in adipose-tissue pyruvate dehydrogenase activity in starved, fat-fed and diabetic rats. Biochem. Soc. Trans., 3, 718-720.

TAYLOR, S.I., MUHKERJEE, C. \& JUNGAS, R.L. (1973). Studies on the mechanism of activation of adipose-tissue pyruvate dehydrogenase by insulin. J. Biol. Chem., 248, 73-81.

TAYLOR, S.I., MUKHERJEE, C. \& JUNGAS, R.L. (1975). Regulation of pyruvate dehydrogenase in isolated rat liver mitochondria. Effects of octanoate oxidation reduction state, and adenosine triphosphate to adenosine diphosphate ratio. J. Biol. Chem., 250, 2028-2035.

WALAJTYS-RODE, E.I. (1976). Studies on the influence of fatty acids on pyruvate dehydrogenase interconversion in rat-liver mitochondria. Eur. J. Biochem., 71, 229. 237.

WIELAND, O,, SIESS, E., SCHULZEWETHMAR, F.H., V. FUNCKE, H.G. \& WINTON, B. (1971). Active and inactive forms of pyruvate dehydrogenase in rat heart and kidney: Effect of diabetes, fasting and refeeding on pyruvate dehydrogenase interconversion. Arch. Biochem. biophys., $143,593-601$. 